\title{
Maternal Thyroid Functions in Pre-Eclampsia
}

\author{
Ümit Naykı1', Cenk Naykı1', Paşa Uluğ'1, Gökalp Öner', Yusuf Yıldırım', Cüneyt Eftal Taner²
}

\begin{abstract}
ÖZET:
Preeklampside maternal tiroid fonksiyonları

Amaç: Çalışmamızda, preeklampsi ile tiroid hormonları arasındaki ilişkiyi incelemeyi amaçladık.

Gereç ve Yöntem: Bu çalışmada, serum tiroid stimule edici hormon (TSH), serbest triiodotironin (FT3) ve serbest tiroksin düzeyleri (FT4) 50 preeklamptik gebe ve 30 normotansif gebede doğumdan önce prospektif olarak ölçüldü. Her iki grup da 3. trimesterdeki gebelerden oluşmaktaydı. Gruplar tiroid hormonları ve obstetrik sonuçlar açısından karşılaştırıldı.

Bulgular: Serum TSH, FT3 ve FT4 düzeyleri açısından iki grup arasında anlamlı bir fark saptanmadı. Ancak, doğum haftası ve doğum ağırlığı açısından her iki grup arasındaki fark istatistiksel olarak anlamlıydı. Normotansif kontroller ile karşılaştırılığında, preeklamptik hastalar daha erken gebelik haftasında doğurdular ve bu grupta, yenidoğan doğum ağırlığı daha düşüktü. Diğer yandan, iki grupta da, tiroid fonksiyonları ve doğum ağırlığı arasında anlamlı korelasyon saptanmadı.

Sonuç: Bulgularımız, tiroid fonksiyonlarının preeklampside değişmediğini göstermektedir. Bu nedenle gebelikte tiroid hormonlarının preeklampsiyi ön görmede kadın doğum hekimlerine yardımcı olamayacağı kanısındayız.
\end{abstract}

Anahtar kelimeler: Gebelik, tiroid fonksiyonu, preeklampsi, doğum ağırlığı

\section{ABSTRACT: \\ Maternal thyroid functions in pre-eclampsia}

Objective: In this study, we aimed to evaluate the relationship between pre-eclampsia and thyroid profile.

Material and Method: In this case control study, serum concentrations of thyroid-stimulating hormone (TSH), free triiodothyronine (FT3) and free thyroxine (FT4) were prospectively measured in fifty preeclamptic patients compared with thirty normotensive pregnant controls before labor. Both groups were composed of various pregnant females in the third trimester. Two groups were also compared with regard to obstetrical outcomes.

Results: Levels of TSH, FT3 and FT4 showed no significant difference between the pre-eclamptic group and normotensive controls. Regarding obstetrical outcomes; the difference was found to be significant for gestational age when studying labor and birth-weight between two groups. Preeclamptic patients delivered at earlier gestation and had lower infant birth-weights compared with normotensive controls. Also, we did not find any statistically significant correlation between thyroid function and birth-weight in both groups.

Conclusion: Our findings suggest that thyroid function does not change in pre-eclampsia. Therefore, the identification of thyroid hormone in pregnancy can not help obstetricians to predict the occurrence of pre-eclampsia.

Key words: Pregnancy, thyroid function, pre-eclampsia, birth-weight

Ş.E.E.A.H. Tıp Bülteni 2014;48(4):308-311
'Erzincan University Medical Faculty,

Department of Obstetrics and Gynaecology, Erzincan-Turkey

${ }^{2}$ Aegean Obstetrics and Gynecology Training and Research Hospital, Obstetrics and

Gynaecology Unit, Izmir-Turkey

Yazışma Adresi / Address reprint requests to: Ümit Naykı,

Yavuz Selim Mah. Ersite Asude Yapı

Kooperatifi, B blok K: 2 D: 4, Erzincan-Turkey

Telefon / Phone: +90-446-212-2216

Faks / Fax: +90-446-212-2211

E-posta / E-mail:

drumit75@hotmail.com

Geliş tarihi / Date of receipt:

12 Şubat 2014 / February 12, 2014

Kabul tarihi / Date of acceptance: 21 Nisan 2014 / April 21, 2014

\section{INTRODUCTION}

Pre-eclampsia is a multisystem disorder characterized by hypertension and proteinuria leading to maternal and perinatal mortality and morbidity (1). The etiopathogenesis of pre-eclampsia has not been fully understood, yet. It is believed that uteroplacental dysfunction may cause changes in normal physiology of pregnancy, especially in third trimester. There have been many reasons considered to explain placental and endothelial dysfunction in pre-eclampsia such as genetic factors, environmental factors, immunological factors and endocrinological factors (1-3).

During normal pregnancy, changes in thyroid functions are well documented. However, information 
about thyroid functions in pre-eclampsia is limited. Thyroid activity undergoes many alterations due to high circulating estrogen levels during normal pregnancy (2). There is a significant increase in thyroglobulin (TGB), total T4 (TT4) and total T3 (TT3). It is known that human chorionic gonadotropin (HCG) is stimulating thyroid gland, because alpha subunits of HCG and thyroid stimulating hormone (TSH) is identical. Also, renal iodide clearance increases due to increased glomerular filtration $(3,4)$. In pre-eclampsia, the failure of estrogen production results in lower TGB, TT3 and TT4 levels along with growth retardation of the foetus (5). There is a high incidence of hypothyroidism in pre-eclampsia which might correlate with the severity of disease (5-7). On the other hand, it has been reported that women with subclinical hypothyroidism identified during pregnancy have an increased risk of severe preeclampsia when compared with euthyroid women (8). However, Casey et al. (9) did not observe any increased incidence of pre-eclampsia in subclinically hypothyroid women. There are controversies surrounding the mechanism and clinical significance of hypothyroidism in pre-eclamptic women, which are attributed to decreased plasma protein concentrations and high levels of endothelin, a potent vasoconstrictor produced after vascular injury $(5,7,10)$.

This study was conducted to evaluate thyroid function in pre-eclamptic patients.

\section{MATERIAL AND METHOD}

Fifty pre-eclamptic pregnant women together with thirty healty pregnant women as controls were prospectively studied. Pre-eclampsia was diagnosed in the second trimester as a blood pressure of 140/90 $\mathrm{mmHg}$ on at least two occasions, six hours apart and the presence of proteinuria which was diagnosed due to $1+$ or more with uristix. The exclusion criteria for both groups were (a) history of any metabolic disorder or medication that might affect thyroid function, (b) history of chronic hypertension, (c) history of renal disease and (d) twin pregnancy.

Both groups were composed of pregnant females in the third trimester of gestation.

Each woman was informed about the study, and provided their approval. Also, the study was approved by the ethics committee of our hospital.

Blood samples were taken before labor. Serum concentrations of freeT3 (triiodothyronine), freeT4 (thyroxine) and TSH (thyroid-stimulating hormone) were measured by immunochemiluminescence using an automated analyser (Immulite 2000). All women were followed up through their intrapartum and postnatal period.

Pre-eclamptic and normal pregnant women were compared for thyroid functions and obstetrical outcomes.

All data are expressed as mean \pm standard deviation (SD). To test for differences between the two groups, the t-test and Mann-Whitney $U$ test were used. Pearson correlation test was applied for the analysis of correlation between birth-weight and thyroid functions. Statistical significance was considered as $\mathrm{p}<0.05$.

\section{RESULTS}

Table 1 shows the clinical characteristics of women in the study and control groups. The mean age of the study group and control group was 26.84 \pm 6.05 years and $28.3 \pm 5.60$ years, respectively. There was no statistically significant difference between the two groups ( $p>0.05)$. While $56 \%$ of women in the study group were nulliparous, the ratio of nulliparous women in the control group was $26.6 \%$. The difference was statistically significant by Mann Whitney $U$ Test $(p<0.05)$. The mean systolic and diastolic blood pressures were 157.40 $\pm 14.29 \mathrm{mmHg}$ and $106.60 \pm 9.97 \mathrm{mmHg}$, respectively, in the preeclamptic study group. However, the mean systolic and diastolic pressures were $103.16 \pm 11.99 \mathrm{mmHg}$ and $68.50 \pm 8.52 \mathrm{mmHg}$ in the control group. The difference between the groups was found to be statistically significant by t-test $(p<0.05)$.

In the pre-eclamptic group, the mean gestational age at the onset of the labor was $35.44 \pm 3.13$ weeks, while this was $38.03 \pm 2.04$ weeks in the control group. There was a statistically significant difference between the two groups $(p<0.05)$. Also, the difference was statistically significant between the two groups when analysing birth-weight $(p<0.05)$. We found a 
Tablo 1: Clinical Characteristics of the Patients

\begin{tabular}{lcc}
\hline & $\begin{array}{c}\text { Preeclamptic pregnant } \\
\text { females }\end{array}$ & $\begin{array}{c}\text { Normal pregnant } \\
\text { females }\end{array}$ \\
\hline Age (years) & $* 26.846 \pm 6.05$ & $* 28.3 \pm 5.60$ \\
Parity(nulliparous / multiparous) & $23 / 27$ & $8 / 22$ \\
SBP $(\mathrm{mmHg})$ & $* 157.40 \pm 14.29$ & $* 103.16 \pm 11.99$ \\
DBP (mmHg) & $* 106.60 \pm 9.97$ & $* 68.50 \pm 8.52$ \\
Gestational age (week) & $* 35.44 \pm 3.13$ & $* 38.03 \pm 2.04$ \\
Delivery & 25 & 6 \\
$\quad$ - C/S & 25 & 24 \\
$\quad$ Vaginal delivery & $* 2604.00 \pm 644.2$ & $* 3430.66 \pm 575.5$ \\
Birth weight (g) & &
\end{tabular}

Tablo 2: Evaluation of thyroid functions in preeclamptic and normal pregnant females

\begin{tabular}{lcc}
\hline & $\begin{array}{c}\text { Preeclamptic pregnant } \\
\text { females }\end{array}$ & $\begin{array}{c}\text { Normal pregnant } \\
\text { females }\end{array}$ \\
\hline TSH $(\mathrm{mlU} / \mathrm{ml})$ & $2.41 \pm 1.33$ & $2.51 \pm 1.16$ \\
FT3 $(\mathrm{ng} / \mathrm{ml})$ & $3.23 \pm 1.01$ & $2.96 \pm 0.83$ \\
FT4 $(\mathrm{ng} / \mathrm{ml})$ & $1.58 \pm 1.34$ & $1.28 \pm 0.33$ \\
\hline *Data are presented as mean \pm standard deviation & &
\end{tabular}

Tablo 3: Correlation of thyroid functions and birthweight in two groups

\begin{tabular}{lcccc} 
& & & Birth weight & \multicolumn{1}{c}{ Normal pregnant females } \\
\hline & $\mathbf{r}$ & $\mathbf{P}$ & $\mathbf{r}$ & $\mathbf{P}$ \\
\hline TSH & 0.17 & 0.23 & 0.225 & 0.233 \\
FT3 & 0.10 & 0.47 & 0.259 & 0.168 \\
FT4 & 0.12 & 0.40 & 0.337 & 0.069
\end{tabular}

lower birth-weight in the pre-eclamptic group than in the normotensive group (Table 1).

Although FT3, FT4 levels of preeclamptic group were higher and TSH levels were lower, there was no statistically significant difference between the groups (p>0.05) (Table 2).

There was a slightly positive correlation between birth-weight and thyroid function (TSH, FT3, FT4) in the pre-eclamptic group, which was not statistically significant ( $p>0.05$; Table 3$)$. In the control group, the correlation between birth-weight and TSH was also found weak positive and statistically nonsignificanct. According to the Pearson correlation test, there was a positive, mild and statistically nonsignificant correlation between birth-weight and FT3 or FT4 (Table 3).

\section{DISCUSSION}

Pre-eclampsia and eclampsia are severe complications of pregnancy and have an important role in pregnancy outcome. In recent years, the relationship between thyroid function and complicated pregnancies has been a matter of concern. However, there is still controversy surrounding this topic.

In the present study, there was no significant difference in the levels of FT3, FT4 and TSH between the pre-eclamptic group and normotensive controls in the third trimester of gestation. Our findings supported the report of Qublan et al. (11) who reported that thyroid function did not alter in severe pre-eclamptic women when compared with 
normotensive controls.

In contrast, there are conflicting reports in the literature. Lower TT3 levels in pre-eclamptic patients compared to normotensive pregnant controls were observed in a few studies $(3,5,12)$. During pregnancy, liver and kidney involvement may lead to decreased peripheral conversion of $\mathrm{T} 4$ to $\mathrm{T} 3$, and hence decreased T3 levels (13). Also, "low T3 syndrome" has been reported in pre-eclampsia in the literature (10). In addition, the loss of proteins and protein bound hormones in the urine in pre-eclampsia may contribute to low TT3 levels (14).

Larijani et al. (15) reported increased TSH levels and decreased free and total levels of T4 and T3 in a study of 39 pre-eclamptic patients compared to 42 healthy controls. These findings are in agreement with others in the literature $(5,16)$.

On the other hand, data in the literature regarding TT4 levels are controversial. A few reports have observed lower TT4 levels in pre-eclampsia $(7,14)$, while others have reported higher TT4 levels (10).

Kumar et al. (2) and Sardana et al. (3) found high levels of TSH in pre-eclamptic patients $(2,3)$, which lends support to earlier reports of a high incidence of biochemical hypothyroidism in pre-eclamptic women when compared with normotensive pregnant women $(7,14,16,17)$.

It has also been observed that pre-eclamptic women with higher TSH levels along with lower thyroid hormones were more likely to have small for gestational age newborns (5-7). TT3 and TT4 concentrations in pre-eclamptic and eclamptic women correlated positively with the birth-weight of their infants $(5,10)$. Lao et al. (7) and Sardana et al. (3) observed a negative correlation between the birthweight of infants and TSH level in pre-eclamptic patients. In our study, a positive correlation between the birth-weight of the infant and thyroid hormones (TSH, FT3 and FT4) in pre-eclamptic patients was observed, although it was not statistically significant. On the other hand, Kumar et al. (2) did not find any correlation between the birth-weight of the newborns and thyroid hormone levels.

According to this study, thyroid function does not change in pre-eclampsia. Therefore, we do not recommend screening pre-eclamptic patients for thyroid dysfunction, regardless of their history. As the sample size of our study was small, further large scale multicentric studies must be conducted to reach a unique agreement on the clinical consequences and outcomes of pregnancies with thyroid disorders.

\section{REFERENCES}

1. Roberts JM, Cooper DW. Pathogenesis and genetics of preeclampsia. Lancet 2001; 357: 53-6.

2. Kumar A, Ghosh BK, Murthy NS. Maternal thyroid hormonal status in preeclampsia. Indian J Med Sci 2005; 59: 57-63.

3. Sardana $D$, Nanda $S$, Kharb $S$. Thyroid hormones in pregnancy and preeclampsia. J Turkish-German Gynecol Assoc 2009; 10: 168-71.

4. Fantz CR, Dagogo-Jack S, Ladenson JH, Gronowski AM. Thyroid function during pregnancy. Clinical Chemistry 1999; 45: 2250-8.

5. Kaya E, Sahin Y, Ozkececi Z, Paşaoğlu H. Relation between birth weight and thyroid function in preeclampsia-eclampsia. Gynecol Obstet Invest 1994; 37: 30-3.

6. Lao TT, Chin RKH, Swaminathan R. Thyroid function in preeclampsia. Br J Obstet Gynaecol 1988; 95: 880-3.

7. Lao TT, Chin RKH, Swaminathan R, Lam YM. Maternal thyroid hormones and outcome of pre-eclamptic pregnancies. $\mathrm{Br} J$ Obstet Invest 1990; 97: 71-4.

8. Wilson KL, Casey BM, McIntire DD, Halvorson LM, Cunningham FG. Subclinical thyroid disease and the incidence of hypertension in pregnancy. Obstet Gynecol 2012; 119: 315-20.

9. Casey BM, Dashe JS, Wells CE, McIntire DD, Byrd W, Leveno $K J$, et al. Subclinical hypothyroidism and pregnancy outcomes. Obstet Gynecol 2005; 105: 239-45.

10. Başbuğ M, Aygen E, Tayyar M, Tutus A, Kaya E, Oktem O. Correlation between maternal thyroid function tests and endothelin in preeclampsia-eclampsia. Obstet Gynecol 1999; 94: 551-5.

11. Qublan HS, Al-Kaisi IJ, Hindiwi IM, Hiasat MS, Awamleh AH, Abd-Alghani I, et al. Severe preeclampsia and maternal thyroid function. J Obstet Gynecol 2003; 23: 244-6.

12. Kharb S, Sardana D, Nanda S. Correlation of thyroid functions with severity and outcome of pregnancy. Ann Med Health Sci Res 2013; 3: 43-46.

13. Skjöldebrand L, Brundin J, Carlström A, Pettersson T. Thyroxinebinding globulin spontaneous abortion. Gynecol Obstet Invest 1986; 21: 187-92.

14. Osathanondt R, Tulchinsky D, Chopra IJ. Total and free thyroxine and triiodothyronine in normal and complicated pregnancy. J Clin Endocrinol Metab 1976; 42: 98-104.

15. Larijani B, Marsoosi V, Aghakhani S, Moradi A, Hashemipour S. Thyroid hormone alteration in preeclamptic women. Gynecol Endocrinol 2004; 18: 97-100.

16. Tolino A, De Conciliis B, Montemagno U. Thyroid hormones in human pregnancy. Acta Obstet Gynecol Scand 1985; 64: 557-9.

17. Khaliq F, Singhal U, Arshad Z, Hassain MM. Thyroid functions in preeclampsia and its correlation with maternal age, parity, severity of blood pressure and serum albumin. Indian J Physiol Pharmacol 1999; 43: 193-8. 